\title{
The Proportion of Lactate Isomers in Farm Silage and the Influence of Inoculation with Lactic Acid Bacteria on the Proportion of L-Lactate in Silage
}

\author{
Yimin $\mathrm{CAl}^{*}$ and Sumio KumAI \\ Faculty of Agriculture, Ehime University, Matsuyama-shi 790
}

(Received May 14, 1993)

\begin{abstract}
In the first part of the study, forty samples of Italian ryegrass (Lolium multiflorum Lam.) and corn (Zea mays L.) silages were collected from dairy farms in Ehime Prefecture and these were used to analyze the quality and proportion of $\mathrm{L}$ - and $\mathrm{D}$-lactate to total lactate in silage. Two other experiments were then conducted using Italian ryegrass and corn to investigate the effect of lactic acid bacteria (LAB) inoculation on the quality and proportion of L-lactate isomers in silage. In Experiment 1, the silage materials were treated with either inoculant S1 containing Lactobacillus casei or inoculant Cy containing both L. casei and Lactococcus lactis. In Expt. 2, the silage materials were inoculated with one or two of the following : Enterococcus faecium, L. lactis and $L$. casei. The proportion of L-lactate to total lactate of the silage from dairy farms was $32-$ $38 \%$. In Expt.1 and Expt. 2, the silage samples inoculated with LAB had a lower pH value, more lactate and a higher FLIEG's score compared to their respective controls. In Expt. 1, the proportion of L-lactate in S1- and $\mathrm{Cy}$-treatments was $5-10 \%(\mathrm{P}<0.05)$ higher than the controls. In Expt, 2 , the proportion was $7-11 \%(\mathrm{P}<0.05)$ higher in lactate-producing cocci treatment and was $12-14 \%$ $(\mathrm{P}<0.05)$ higher in lactobacilli or mixed treatment than their respective controls. The LAB inoculant mixture did not result in advantageous effect over the inoculation of lactobacilli alone. The results confirmed that the inoculation of LAB, especially lactobacilli, had the beneficial effect for increasing $\mathrm{L}$-lactate content in silage, thus for improving silage quality.
\end{abstract}

Anim. Sci. Technol. (Jpn.) 65 (9) : 788-795, 1994

Key words : lactic acid bacteria, lactate isomers, silage

Two isomers of lactate, $\mathrm{L}(+)$-lactate and $\mathrm{D}$ (-)-lactate, are produced by lactic acid bacteria (LAB) in silage. In animals, the L-lactate is more effectively utilized within the body than the D-lactate ${ }^{7,8,19,20,25)}$. In Japan, concentrates are widely used as the main component of the diet for cattle. Excessive intake of concentrates and silage containing high amounts of D-lactate leads to an unusual accumulation of D-lactate in the reticulorumen and blood, which may be associated with the development of lactic acidosis in ruminants ${ }^{2,8,25)}$. Recently, a year-round silage feeding system has spread to many dairy farms in Japan. Under this feeding system, increasing L-lactate content in silage may introduce an important to ruminant health and nutrition problems. Research concerning the effects of inoculation of $L A B$ on the quality of various silage has been report$\mathrm{ed}^{2,4,9,11,13,22,23)}$, but there are very few reports on the $\mathrm{L}$ - and $\mathrm{D}$-isomers of lactate in silage on dairy farms and the effects of LAB inoculation on lactate isomers. The objectives of this study were:

* Present address : National Grassland Research Institute, Nishinasuno-machi, Tochigi-ken 329-27 
(1) to investigate the proportion of lactate isomers in dairy farm silage, and (2) to investigate the effects of $\mathrm{LAB}$ inoculation on the proportion of $\mathrm{L}$ - and $\mathrm{D}$-lactate isomers in silage made in laboratory silos.

\section{Materials and Methods}

Sample collection of dairy farm silages: A total of 40 samples, consisting of 6 high moisture Italian ryegrass silages (IRH), 10 medium moisture Italian ryegrass silages (IRM) and 24 corn silages were collected from dairy farms in Ehime Prefecture. In making these farm silages, the Italian ryegrass was cut at the heading or flowering stage and the corn was cut at the dough or yellow ripe stage. The IRH $(78.3-82.9 \%$ moisture), IRM (61.9-68.9\% moisture) and corn silage (66.7-74.7\% moisture) were made on dairy farms between October 1989 and December 1990, without any additives including commercial inoculants, in large polyethylene vessels or tower silos. The silages were analyzed for the quality and proportion of $\mathrm{L}$-lactate isomer.

Laboratory silage preparation: Expt. 1 ; Italian ryegrass and corn were grown in an experimental field of the Faculty of Agriculture, Ehime University. The second regrowth of Italian ryegrass at the heading stage was cut on May 20, 1989. Corn at the silking stage (corn S) and ripe stage (corn R) were cut on August 12, 1989 August 8, 1990, respectively. The chemical composition and viable counts of microorganisms in silage materials are shown in Table 1. These materials were chopped into about $20 \mathrm{~mm}$ lengths and ensiled into $300 \mathrm{l}$ capacity polyethylene vessels. Prior to ensiling, the materials were either untreated (Co) or treated with one of the following bacterial inoculants: Sl, which contained a single strain of the organism Lactobacillus casei (Lc) or Cy, which contained a mixture of $\mathrm{LC}$ and Lactococcus lactis (LI). The Sl was targeted to provide $1.0 \times 10^{5}$ colony forming units (cfu) of Lc. The Cy was added with $7.0 \times 10^{4} \mathrm{cfu}$ of $\mathrm{Lc}$ plus $3.0 \times 10^{4} \mathrm{cfu}$ of $\mathrm{Ll} \mathrm{g}^{-1}$ on a fresh matter basis. There were four replications per treatment. The silos were opened 90 days after ensiling for chemical analyses of silage. Expt. 2 ; Italian ryegrass and corn were grown in a farmer's field in Kawauchi Town, Ehime Prefecture. The second regrowth of Italian ryegrass at the heading stage was cut on July 28 , 1990 and wilted for 4 hours. The corn at early yellow ripe stage was cut on August 8, 1990. The chemical composition and viable count of microorganisms in the materials are shown in Table 1. These materials were chopped into

Table 1. Chemical composition $(\% \mathrm{DM})$ and viable count of microorganisms of materials $\left(\mathrm{g}^{-1}\right.$ on a fresh matter basis)

\begin{tabular}{|c|c|c|c|c|c|c|c|c|c|c|c|}
\hline Material & $\begin{array}{l}\text { Mois- } \\
\text { ture }\end{array}$ & $\begin{array}{l}\text { Crude } \\
\text { protien }\end{array}$ & $\begin{array}{l}\text { Crude } \\
\text { fat }\end{array}$ & $\begin{array}{l}\text { Crude } \\
\text { fiber }\end{array}$ & $\mathrm{NFE}^{\mathrm{a})}$ & $\begin{array}{l}\text { Crude } \\
\text { ash }\end{array}$ & $\mathrm{WSC}^{\mathrm{b})}$ & $\begin{array}{l}\text { Aerobic } \\
\text { bacteria }\end{array}$ & $\begin{array}{c}\text { Mold \& } \\
\text { Yeast }\end{array}$ & $\begin{array}{l}\text { Lacto- } \\
\text { cocci }{ }^{-1}\end{array}$ & $\begin{array}{l}\text { Lacto- } \\
\text { bacilli }\end{array}$ \\
\hline \multicolumn{12}{|l|}{ Exp. 1.} \\
\hline Italian ryegrass & 84.3 & 6.1 & 3.4 & 29.8 & 52.4 & 8.3 & 10.3 & $3.5 \times 10^{5}$ & $2.1 \times 10^{4}$ & $1.0 \times 10^{3}$ & $5.0 \times 10^{2}$ \\
\hline Corn $\mathrm{S}^{\mathrm{d})}$ & 85.6 & 11.2 & 2.2 & 32.6 & 44.8 & 9. 2 & 6.0 & $6.7 \times 10^{6}$ & $3.3 \times 10^{5}$ & $5.6 \times 10^{9}$ & 1. $2 \times 10^{3}$ \\
\hline Corn $R^{e)}$ & 71.0 & 5.9 & 3.2 & 17.3 & 66.9 & 6.7 & 16.4 & $9.2 \times 10^{5}$ & $8.2 \times 10^{4}$ & $1.6 \times 10^{4}$ & $7.3 \times 10^{3}$ \\
\hline \multicolumn{12}{|l|}{ Expt. 2.} \\
\hline Italian ryegrass & 66.3 & 9.1 & 3.5 & 26.5 & 51.0 & 9.9 & 11.5 & $2.7 \times 10^{5}$ & $3.6 \times 10^{4}$ & $2.5 \times 10^{3}$ & $7.7 \times 10^{2}$ \\
\hline Corn & 75.2 & 6.7 & 2.6 & 21.0 & 64.5 & 5.2 & 17.9 & 1. $3 \times 10^{6}$ & $2.9 \times 10^{5}$ & $2.2 \times 10^{4}$ & $5.6 \times 10^{3}$ \\
\hline
\end{tabular}

\footnotetext{
a) : Nitrogen free extract.

b) : Water soluble carbohydrates.

c) : Including lactococci, enterococci, streptococci, leuconostocs and pediococci.

d) : Corn at silking stage.

e) : Corn at ripe stage.
} 


\section{CAI and Kumai}

about $20 \mathrm{~mm}$ length and ensiled into $1 l$ laboratory silos. Two species of lactate-producing cocci (Enterococcus faecium and $\mathrm{Ll}$ ) and one specie of lactobacilli (Lc) were used. Treatments were (1) Co, (2) E. faecium (Ef), (3) Ll, (4) Lc, (5) Lc+Ef and (6) Lc + Ll. The inoculants Ef, $\mathrm{Ll}$ and Lc were targeted to give $1.0 \times 10^{5} \mathrm{cfu}$ of $\mathrm{LAB}, \mathrm{Lc}+\mathrm{Ef}$ and $\mathrm{Lc}+\mathrm{Ll}$ with $1.0 \times 10^{5} \mathrm{cfu}$ of Lc plus $5.0 \times 10^{4} \mathrm{cfu}$ of $\mathrm{Ef}$ and $\mathrm{Llg}^{-1}$ on a fresh matter basis, respectively. There were four replications per treatment. The silos were opened 90 days after ensiling.

Microorganism enumeralion: Ten grams of the silage materials were shaken with $90 \mathrm{ml}$ of sterilized $0.85 \%$ sodium chloride $(\mathrm{NaCl})$ solution, and $10^{-1}-10^{-8}$ serial dilutions were made in $0.85 \% \mathrm{NaCl}$ solution. The plating media were nutrient agar $^{26)}$ for aerobic bacteria and potato dextrose agar $^{26)}$ for mold and yeast. Lactate-producing cocci and lactobacilli were counted using LeE's agar ${ }^{12)}$ and acetate agar ${ }^{16)}$, respectively. The microorganism counts were measured by the plate count method. The plated samples were incubated at $25-30^{\circ} \mathrm{C}$ for $3-$ 4 days. The viable colonies were counted as viable counts of microorganisms $\mathrm{g}^{-1}$ on a fresh matter basis.

Chemical analyses: The chemical composition of materials was determined by the conventional method. Water soluble carbohydrate (WSC) in the material was estimated colorimetrically using anthrone reagent ${ }^{18)}$. The moisture content of the material and silage were determined by the toluene distillation $\operatorname{method}^{17)}$. The measurement of $\mathrm{pH}$ was carried out with a glass electrode $\mathrm{pH}$ meter and organic acid content was measured by FLIEG's distillation method ${ }^{18)}$.

The L- and D-lactate isomers were determined according to the UV-method for determination of lactate as described below. Fifty grams of silage sample were mixed with $200 \mathrm{~m} l$ distilled water in a $500 \mathrm{~m} l$ volumetric flask and placed in a refrigerator for $12 \mathrm{~h}$ at $5^{\circ} \mathrm{C}$ with occasional shaking. After filtration, the extracted solution was placed in a water-bath at $80^{\circ} \mathrm{C}$ for $15 \mathrm{~min}$ to stop any enzy matic reaction. The solution was then centrifuged and the supernatant was used for the enzymatic assay ${ }^{21)}$.

Statistical analysis: Data were analyzed by analysis of variance and the significance of differences among means was tested by Duncan's Multiple range test ${ }^{6}$.

\section{Results}

The quality and proportion of L-lactate in dairy farm silage is shown in Table 2. The IRM and corn silage had lower $\mathrm{pH}$ values, more lactate content and higher FLIEG's scores than IRH silage.

The proportions of L-lactate and D-lactate to total lactate content in IRH, IRM and corn silage were $32-38 \%$ and $62-68 \%$, respectively. Thus, it was confirmed that D-lactate was the predominant isomer in these dairy farm silages.

Table 2. The quality and proportion of L-lactate in dairy farm silages

\begin{tabular}{|c|c|c|c|c|c|c|c|c|c|c|c|}
\hline \multirow{2}{*}{ Silage } & \multirow{2}{*}{$\begin{array}{c}\text { Number } \\
\text { of } \\
\text { samples }\end{array}$} & \multirow{2}{*}{$\begin{array}{l}\text { Moisture } \\
(\%)\end{array}$} & \multirow{2}{*}{$\mathrm{pH}$} & \multicolumn{6}{|c|}{ Organic acid ( $\%$ in fresh matter) } & \multirow{2}{*}{$\begin{array}{c}\text { FLIEG's } \\
\text { score }\end{array}$} & \multirow{2}{*}{$\frac{L(+)^{c)}}{T-L}$} \\
\hline & & & & Acetic & Butyric & Lactic & $L(+)^{a)}$ & $D(--)^{b}$ & Total & & \\
\hline $\operatorname{IRH} \mathrm{I}^{\mathrm{d})}$ & $n=6$ & $80.6 \pm 2.3$ & 4.8 & 1.08 & 0.01 & 1.62 & 0.52 & 1. 10 & 2.71 & 70 & 32 \\
\hline $\mathrm{IRM}^{\mathrm{e})}$ & $\mathrm{n}=10$ & $65.4 \pm 3.5$ & 4.0 & 1.09 & 0.00 & 2. 82 & 1.07 & 1.75 & 3.91 & 88 & 38 \\
\hline Corn & $\mathrm{n}=24$ & $70.7 \pm 4.0$ & 4. 1 & 0.58 & 0.00 & 2.58 & 0.92 & 1.66 & 3. 16 & 95 & 36 \\
\hline
\end{tabular}

a) : L-lactate.

b) : D-lactate.

c) : L-lactate/total lactate $\times 100 \%$.

d) : Italian ryegrass with high moisture.

e) Italian ryegrass with medium moisture. 
The effects of LAB inoculants on the quality and proportion of L-lactate in silage in Expt. 1 are shown in Table 3 . Silages made with LAB inoculant had a lower $\mathrm{pH}$ value and a significantly $(\mathrm{P}<0.05)$ higher lactate content than their respective controls. Compared with the control silage samples, the FLIEG's scores of Italian ryegrass, corn $S$ and corn $R$ silage samples treated with $S 1$ and $C y$ were 12 , 25 and 5 points higher, respectively. The Sland $\mathrm{Cy}$-treatments significantly increased the proportion of L-lactate in silage by $5-6 \%(\mathrm{P}<$ $0.05)$ for Italian ryegrass silage and $6-10 \%(\mathrm{P}<$ $0.05)$ for corn silage over their respective controls.

The effects of LAB inoculation on the quality and proportion of L-lactate in silage in Expt. 2 are shown in Table 4. The FliEg's score in all treatments was 100 points for Italian ryegrass silage and 95 points for corn silage. However, $\mathrm{Lc}, \mathrm{Cf}$ and $\mathrm{Cl}$ treated silage had significantly ( $\mathrm{P}$ $<0.05)$ lower $\mathrm{pH}$ values and significantly $(\mathrm{P}<$
0.05 ) higher lactate content $\mathrm{Co}$, Ef and $\mathrm{Ll}$ treatments. In Italian ryegrass silage, the proportion of L-lactate was 7-9\% $(\mathrm{P}<0.05)$ more for $\mathrm{Ef}$ and $\mathrm{L} 1$ treatments and $12-14 \%(\mathrm{P}<0.05)$ more for $\mathrm{Lc}, \mathrm{Lc}+\mathrm{Ef}$ and $\mathrm{Lc}+\mathrm{Ll}$ treatments than those of the controls. In corn silage, the proportion of L-lactate was $9-11 \%(\mathrm{P}<0.05)$ more in $\mathrm{Ef}$ and $\mathrm{Ll}$ treatments, and $13-14 \%(\mathrm{P}<0.05)$ more in $\mathrm{Lc}, \mathrm{Lc}+\mathrm{Ef}$ and $\mathrm{Lc}+\mathrm{Ll}$ treatments than those of the controls. Therefore, the inocula tion of lactobacilli provided beneficial effects by increasing L-lactate content compared to lactate-producing cocci. The inoculation of lactobacilli plus enterococci or lactococci did not result in greater effect than lactobacilli inoculation alone.

\section{Discussion}

Proportion of $L$ - and $D$-lactate in dairy farm silage: Lactobacilli and lactate-producing cocci such as lactococci, streptococci, enterococci, leuconostocs and pediococci mainly

Table 3. The quality and proportion of L-lactate of silages in Expt. $1^{\text {a) }}$

\begin{tabular}{|c|c|c|c|c|c|c|c|c|c|c|}
\hline \multirow{2}{*}{$\begin{array}{c}\text { Silage } \\
\text { treatment }\end{array}$} & \multirow{2}{*}{$\begin{array}{l}\text { Moisture } \\
(\%)\end{array}$} & \multirow{2}{*}{$\mathrm{pH}$} & \multicolumn{6}{|c|}{ Organic acid (\% in fresh matter) } & \multirow{2}{*}{$\begin{array}{l}\text { FLIEG'S } \\
\text { score }\end{array}$} & \multirow{2}{*}{$\frac{L(+)^{d)}}{T-L}$} \\
\hline & & & Acetic & Butyric & Lactic & $L(t)^{b)}$ & $\mathrm{D}(-)^{\mathrm{c})}$ & Total & & \\
\hline \multicolumn{11}{|c|}{ Italian ryegrass } \\
\hline $\mathrm{Co}^{\mathrm{e})}$ & 82.4 & 4. $1^{\Lambda}$ & $1.09^{\mathrm{A}}$ & 0.00 & $2.82^{\mathrm{B}}$ & $1.07^{\mathrm{B}}$ & $1.75^{\mathrm{B}}$ & $3.91^{\mathrm{B}}$ & 88 & $38^{B}$ \\
\hline $\mathrm{Sl}^{\eta}$ & 81.8 & $3.8^{A}$ & $0.66^{B}$ & 0.00 & $3.59^{\mathrm{A}}$ & 1. $54^{\mathrm{A}}$ & $2.05^{\mathrm{AB}}$ & 4. $25^{A B}$ & 100 & $43^{A}$ \\
\hline$C y^{g)}$ & 82.1 & 3. $8^{A}$ & $0.68^{\mathrm{B}}$ & 0.00 & $3.76^{A}$ & $1.65^{A}$ & $2.11^{A}$ & 4. $44^{\mathrm{A}}$ & 100 & $44^{\mathrm{A}}$ \\
\hline \multicolumn{11}{|l|}{ Corn $S^{h\rangle}$} \\
\hline Co & 83.4 & 4. $4^{\mathrm{A}}$ & $0.91^{\mathrm{A}}$ & 0.00 & 1. $36^{\mathrm{B}}$ & $0.34^{\mathrm{B}}$ & $1.02^{\mathrm{A}}$ & $2.28^{\mathrm{A}}$ & 70 & $25^{\mathrm{C}}$ \\
\hline Sl & 83. 4 & $3.8^{\mathrm{B}}$ & $0.54^{\mathrm{B}}$ & 0.00 & $1.92^{\mathrm{A}}$ & $0.67^{A}$ & 1. $25^{\mathrm{A}}$ & 2. $46^{\mathrm{A}}$ & 95 & $35^{\AA}$ \\
\hline Cy & 83.3 & $3.8^{\mathrm{E}}$ & $0.51^{\mathrm{B}}$ & 0.00 & 1. $94^{\mathrm{A}}$ & $0.67^{A}$ & 1. $27^{\mathrm{A}}$ & 2. $45^{\mathrm{A}}$ & 95 & $34^{\mathrm{A}}$ \\
\hline \multicolumn{11}{|l|}{ Corn $\mathrm{R}^{\mathrm{i}}$} \\
\hline Co & 69.2 & $3.8^{\mathrm{A}}$ & $0.70^{\mathrm{A}}$ & 0.00 & $2.54^{\mathrm{B}}$ & $0.84^{\mathrm{B}}$ & $1.70^{\mathrm{A}}$ & 3. $24^{\mathrm{A}}$ & 95 & $33^{c}$ \\
\hline Sl & 68.5 & 3. $4^{\mathrm{A}}$ & $0.38^{B}$ & 0.00 & $3.12^{\mathrm{A}}$ & 1. $22^{A}$ & $1.90^{\mathrm{A}}$ & $3.50^{\mathrm{A}}$ & 100 & $39^{A B}$ \\
\hline $\mathrm{Cy}$ & 68.7 & $3.5^{A}$ & $0.40^{\mathrm{B}}$ & 0.00 & 3. $20^{\mathrm{A}}$ & 1. $34^{\mathrm{A}}$ & 1. $86^{\mathrm{A}}$ & 3. $60^{A}$ & 100 & $42^{\mathrm{A}}$ \\
\hline
\end{tabular}

a) : Silo : 300 liter capacity polyethylene vessels; silo opening : 90 days after ensiling.

b),c),d) : Refer to Table 2.

e) : Control.

i) : Lactobacillus casei inoculant.

${ }^{8)}$ : L. casei and Lactococcus lactis inoculant.

h) : Corn at silking stage.

i) : Corn at ripe stage.

${ }_{A B C}:$ Means in the same column with different superscripts are significantly different $(\mathrm{P}<0.05)$. 
CAI and KumaI

Table 4. The quality and proportion of L-lactate of silages in Expt. $2^{\text {a) }}$

\begin{tabular}{|c|c|c|c|c|c|c|c|c|c|c|}
\hline \multirow{2}{*}{$\begin{array}{l}\text { Silage } \\
\text { treatment }\end{array}$} & \multirow{2}{*}{$\begin{array}{l}\text { Moisture } \\
(\%)\end{array}$} & \multirow{2}{*}{$\mathrm{pH}$} & \multicolumn{6}{|c|}{ Organic acid (\% in fresh matter) } & \multirow{2}{*}{$\begin{array}{l}\text { FLIEG's } \\
\text { score }\end{array}$} & \multirow{2}{*}{$\frac{\mathrm{L}(+)^{\mathrm{d}}}{\mathrm{T}-\mathrm{L}}$} \\
\hline & & & Acetic & Butyric & Lactic & $L(+)^{b)}$ & $\mathrm{D}(-)^{\mathrm{C})}$ & Total & & \\
\hline \multicolumn{11}{|c|}{ Italian ryegrass (wilted) } \\
\hline $\mathrm{Co}^{\mathrm{e})}$ & 64.4 & 4. $2^{\mathrm{A}}$ & $0.69^{A}$ & 0.00 & 4. $27^{\mathrm{B}}$ & $1.41^{\mathrm{C}}$ & 2. 86 & 4. $96^{\mathrm{B}}$ & 100 & $33^{\mathrm{c}}$ \\
\hline $\mathrm{Ef}^{()}$ & 64.8 & 4. $0^{\mathrm{A}}$ & $0.58^{\mathrm{A}}$ & 0.00 & 4. $58^{\mathrm{B}}$ & $1.92^{\mathrm{B}}$ & 2.66 & 5. $16^{\mathrm{B}}$ & 100 & $42^{A \mathrm{~B}}$ \\
\hline $\mathrm{LI}^{\mathrm{g})}$ & 65.1 & 4. $0^{\mathrm{A}}$ & $0.56^{A}$ & 0.00 & $4.47^{\mathrm{B}}$ & 1. $79^{\mathrm{B}}$ & 2.68 & $5.03^{\mathrm{B}}$ & 100 & $40^{\mathrm{B}}$ \\
\hline$L c^{h)}$ & 64.3 & 3. $5^{\mathrm{B}}$ & $0.39^{\mathrm{B}}$ & 0.00 & $5.17^{\mathrm{A}}$ & $2.38^{\mathrm{A}}$ & 2.79 & $5.56^{A}$ & 100 & $46^{A}$ \\
\hline $\mathrm{Lc}+\mathrm{Ef}$ & 65.4 & $3.5^{\mathrm{B}}$ & $0.42^{\mathrm{B}}$ & 0.00 & $5.15^{\mathrm{A}}$ & 2. $42^{\mathrm{A}}$ & 2. 73 & 5. $57^{A}$ & 100 & $47^{\mathrm{A}}$ \\
\hline $\mathrm{Lc}+\mathrm{Ll}$ & 65.4 & 3. $5^{\mathrm{B}}$ & $0.47^{\mathrm{B}}$ & 0.00 & $5.21^{A}$ & $2.34^{\mathrm{A}}$ & 2.87 & $5.68^{A}$ & 100 & $45^{A}$ \\
\hline \multicolumn{11}{|l|}{ Corn } \\
\hline $\mathrm{Co}$ & 72.2 & 3. $9^{\mathrm{A}}$ & $0.35^{\mathrm{B}}$ & 0.00 & $1.48^{B}$ & $0.36^{\mathrm{C}}$ & 1. 12 & 1. $83^{\mathrm{B}}$ & 95 & $24^{c}$ \\
\hline Ef & 72.5 & 3. $7^{\mathrm{A}}$ & $0.36^{B}$ & 0.00 & $1.56^{\mathrm{B}}$ & $0.55^{\mathrm{B}}$ & 1.01 & 1. $92^{\mathrm{B}}$ & 95 & $35^{\mathrm{AB}}$ \\
\hline $\mathrm{Ll}$ & 71.8 & 3. $7^{\mathrm{A}}$ & $0.38^{\mathrm{B}}$ & 0.00 & $1.59^{\mathrm{B}}$ & $0.52^{\mathrm{B}}$ & 1.07 & 1. $97^{\mathbf{8}}$ & 95 & $33^{\mathrm{B}}$ \\
\hline Lc & 72.0 & $3.5^{\mathrm{B}}$ & $0.45^{A}$ & 0.00 & $1.77^{\mathrm{A}}$ & $0.67^{\mathrm{A}}$ & 1. 10 & 2. $22^{\mathrm{A}}$ & 95 & $38^{A}$ \\
\hline$L c+E f$ & 71.7 & 3. $6^{\mathrm{B}}$ & $0.43^{\mathrm{A}}$ & 0.00 & 1. $73^{\mathrm{A}}$ & $0.65^{A}$ & 1.08 & 2. $16^{\mathrm{AB}}$ & 95 & $38^{A}$ \\
\hline $\mathrm{Lc}+\mathrm{L} 1$ & 71.7 & $3.5^{\mathrm{B}}$ & $0.46^{\mathrm{A}}$ & 0.00 & $1.75^{\mathrm{A}}$ & $0.65^{\mathrm{A}}$ & 1.10 & $2.21^{\mathrm{A}}$ & 95 & $37^{\mathrm{A}}$ \\
\hline
\end{tabular}

a) : Silo : 1 liter laboratory bottles; silo opening : 90 days after ensiling.

b),c), (d) : Refer to Table 2.

e): Control.

D) : Enterococcus faecium.

8): Lactococcus lactis.

h): Lactobacillus case $i$.

${ }^{A B C}:$ Means in the same column with different superscripts are significantly different $(P<0.05)$.

participate in the lactate fermentation of silage ${ }^{5,14,15)}$. The lactococci grew vigorously only in the early stage of ensiling, but the propagation of lactobacilli continued until silage ripening ${ }^{5)}$. Therefore lactobacilli has a large function in determining the period of silage fermentation. Among lactobacilli, Lactobacillus casei exclusively produces $\mathrm{L}$-lactate. $L$. lactis exclusively produces $\mathrm{D}$-lactate, and $L$. plantarum produces a racemic mixture of $L$ and D-lactate ${ }^{15)}$. These LAB are usually present in forage crops and grasses ${ }^{3,15)}$ and they ferment WSC to produce either L-, D-lactate or a mixture of both during silage fermentation $^{4.5 .14,15)}$. In the present experiment, the proportion of L-lactate was below $40 \%$ in the three silage types. Therefore, LAB which exclusively produced D-isomer had numerical or functional superiority in fermentation over LAB which exclusively produced L-isomer. DUNLOP ${ }^{7,8)}$ and HELLINGS et al. ${ }^{10)}$ stated that silage containing very high amounts of lactate may result in the problem of lactic acidosis in ruminants, and that the D-isomer of lactate is very slowly metabolized by gluconeogenesis. SCHAADT and JoHNSON ${ }^{24)}$ found out that, in general, the production of lactate in silage largely involves the D-isomer. ATAKU et al. ${ }^{1)}$ reported that on Hokkaido dairy farms, the proportions of D-lactate in corn and grass silage were $55 \%$ and $56 \%$, respectively. In the present experiment, the proportion of D-lactate in silage showed a higher range of $62-68 \%$. The epiphytic LAB species might change and influence the proportion of lactate isomer in silage according to the location of silage preparation and the time of ensiling.

Influence of inoculation with $L A B$ on proportion of L-lactate in silage: The authors ${ }^{3-5.11)}$ of the present study have reported that when $\mathrm{LAB}$ (especially lactobacilli) are present in very low numbers, the inoculation of lactobacilli 
generally provides beneficial effects by promoting the propagation of lactobacilli and by inhibiting the growth of harmful bacteria such as aerobic bacteria, mold and yeast as well as improving the quality of silage. Hellings et $a l{ }^{10)}$ reported that at least a lavel of $10^{5} \mathrm{~g}^{-1}$ lactobacilli in fresh material is required for good quality of silage. In this experiment, high numbers of aerobic bacteria $\left(10^{5}-10^{6} \mathrm{~g}^{-1}\right)$, mold and yeast $\left(10^{4}-10^{5} \mathrm{~g}^{-1}\right)$, and low numbers of lactate-producing cocci $\left(10^{3}-10^{4} \mathrm{~g}^{-1}\right)$ and lactobacilli $\left(10^{2}-10^{3} \mathrm{~g}^{-1}\right)$ were found in the fresh materials, suggesting the necessity for inoculation with LAB. In Expt. 1, the silage samples inoculated with $\mathrm{Sl}$ and $\mathrm{Cy}$ demonstrated a lower $\mathrm{pH}$ values and a significantly higher lactate content than those of the controls. Consistent with previous reports ${ }^{4,5}$, inoculation with $L A B$ increased the numbers of $L A B$, leading to production of more lactate which reduced $\mathrm{pH}$ values. Both $\mathrm{Sl}-$ and $\mathrm{Cy}-\mathrm{in}$ oculated silage samples showed a significantly higher proportion of L-lactate to total lactate content. The cause was attributed to $\mathrm{Lc}$ which is a homofermentative LAB, producing exclusively $L$-lactate ${ }^{15)}$. These results indicated that the inoculation with $\mathrm{LAB}$ such as Lc increased the L-isomer of lactate and improved the silage quality.

In Expt. 2, the silage samples inoculated with LAB increased lactate content. This would tend to accelerate the decline in silage $\mathrm{pH}$ value and hence improve the silage quality. Compared with the control, the inoculation of the LAB examined in this trial had beneficial effects on the proportion of L-lactate. However, $\mathrm{Lc}, \mathrm{Lc}+\mathrm{Ef}$ and $\mathrm{Lc}+\mathrm{Ll}$ resulted in a greater increase in the proportion of L-lactate than $\mathrm{Ef}$ and Ll. It is assumed that lactate-producing cocci acted as a starter for lactate fermentation in silage, which created an anaerobic environment suitable for the development of lactobacilli, although it was shown that they only played a short-time role at an early stage of the fermentation processes in silage ${ }^{5)}$. On the other hand, lactobacilli played an important role in all fermentation processes and promoted lactate fermentation for a longer time than lactate-producing $\operatorname{cocci}^{5}{ }^{5}$. In the present experiment, lactobacilli plus lactate-producing cocci did not provide greater effects than lactobacilli alone. It was concluded that high levels of lactobacilli $\left(10^{5} \mathrm{~g}^{-1}\right)$ during ensiling enhance the lactate fermentation of silage. The bacteria species of E. faecium, L. lactis and $L$. case $i$ are homofermentative $\mathrm{LAB}$ and can exclusively produce L-lactate. Therefore, silage with these LAB have a higher L-lactate content as well as an increased total lactate content.

In Expt. 1 and Expt. 2, the WSC content of material was relatively low but the lactate content of silage was much higher for Italian ryegrass than corn silage. The reason for this is unclear. However, McDonald et al. ${ }^{15)}$ found that because of the existence of hemicellulase in Italian ryegrass, a considerable amount of the original hemicellulose could be degraded during ensiling, and suggested that there are three possible sources of hemicellulose breakdown : 1) hemicillulases present in the original herbage, 2) bacterial hemicellulases, and 3) hydrolysis by organic acid produced during fermentation. It is possible that the enzyme dergraded the cell wall polysaccharides to WSC, and that if the epiphytic or inoculated LAB can grow at low $\mathrm{pH}$, a large amount of lactate will be produced from the cell wall component in silage. Further studies are needed to clarify the fermentation characteristics of epiphytic LAB and the activity of cell wall degrading enzymes during silage fermentation.

The present results confirmed that the inoculation of LAB, especially lactobacilli, had beneficial effects on decreasing D-lactate content, increasing $\mathrm{L}$-lactate content and improving silage quality. Therefore, in silage preparation, inoculation of the $\mathrm{L}(+)$ optical type of homofermentative LAB such as $L$. casei is recommended from the view point that this 
will improve the silage quality and will decrease the risk of lactic acidosis in ruminants.

\section{References}

1) Ataku, K., N. Narasaki, M. Kikuchi and H. OHARA, Distribution of lactic acid isomer in silage, J. Japan Grassl. Sci., 24 : 165-166. 1978.

2) CaI, Y., S. Kumai, R. Fukumi, L.F. Quinitio and K. TAJI, Effect of lactic acid bacteria inoculants on fermentative quality and digestibility of silage. Proc, 5 AAAP Anim. Sci. Congr., $3: 116$. 1990.

3) $\mathrm{C}_{\mathrm{Al}}, \mathrm{Y}$., S. KumaI and R. Furumi, Effect of altitude and seasonal change in microflora on forage crops and grasses with special reference to lactic acid bacteria. J. Japan Grassi. Sci., 37 : 247-253. 1991.

4) CaI, Y., S. Kumai and R. Fukumi, Effect of inoculation of lactic acid bacteria on the recovery of dry matter, distribution of isomers of lactic acid and nutritive value in silagc. J. Japan Grassl. Sci., 37 : 428-434. 1992.

5) $\mathrm{C}_{\mathrm{Al}}, \mathrm{Y}, \mathrm{S}$. Kumal and R. Fukumi, Effect of inoculation of lactic acid bacteria on the changes of microfora during ensilage and the fermentative quality in corn silage. Mem. Coll. Agr., Ehime Univ., 36 : 497-506. 1992.

6) DUNCAN, D.B., Multiple range and multiple $F$ test. Biometrics. $11: 1-42.1955$.

7) Dunlop, R.H. and P.B. Hammond, D(-) Lactic acidosis of ruminants. Ann. New York. Acad. Sci., 119 : 1109-1132. 1965.

8) Dunlop, R.H., Pathogenesis of ruminant lactic acidosis. Adv. Vet. Sci. Comp., 16:250-302. 1972.

9) GoRdon, F.J., An evaluation through lactating cattle of a bacterial inoculant as an additive for grass silage. Grass and Forage Sci.. 44 : 353357. 1989.

10) Hellings, Ph, G. Bertin and M. Vanbelle, Effect of lactic acid bacteria on silage fermentation. Proc. 15 Int. Grassl. Congr., 932-933. 1985.

11) Kumai, S.,T. Kimura, L. Fukumi, Y. Cai and L.F. Quinirio, Effect of inoculation of lactobacilli at ensiling on the fermentative quality of silage and changes in microflora during ensilage. $J$. Japan Grassl. Sci., 36 : 231-237. 1990.

12) LeE, S.Y., E.R. Vedamuthu, C.J. Waxham and G. $W$. REINBOLD, An agar medium for the differential enumeration of yogurt starter bacteria. J. Milk Food Technol., 37 : 272-276. 1974.
13) Martinsson, K., A study of the efficacy of a bacterial incculant and formic acid as additives for grass silage in terms of milk production. Grass and Forage Sci., 47 : 189-198. 1992.

14) Masuko, T., T. Uchimura, S. OKada and $K$. AWAYA, Relationship between quality of grass silage and flora of lactic acid bacteria. Jpn. J. Zootech. Sci., 63 : 629-637. 1992.

15) McDonald, P., N. Henderson and S. Heron, The biochemistrey of silage. 2nd ed. 48-247. Chalcombe Publications. Great Britain. 1991.

16) MoRICHI, T. and Y. Ohyama, Distribution of lactobacilli on grasses. Jpn. J. Zootech. Sci., 43 : 264-267. 1972.

17) Morimoto, H., Experimental method of animal nutrition (HoRII, S., ed.) 284-285. Youkendo. Tokyo. 1971.

18) Morimoto, H., Experimental method of animal nutrition (Oну Aма, Y., ed.) 419-424. Youkendo. Tokyo. 1971.

19) Newbold, C.J., D.G. Chamberlain and A.G. Wil. LIAMS, The effects of defaunation on the metabolism of lactic acid in the rumen. J. Sci. Food Agric., 37 : 1083-1090. 1986.

20) Newbold, C.J., A.G. Williams and D.G. Cham. BERLAIN, The in-vitro metabolism of D, L-lactic acid by rumen microorganisms. J. Sci. Food Agric., 38 : 9-18. 1987.

21) NolL, F., In methods of enzymatic analysis 3rd ed., vol. VI (BERGMEYER, H.U., ed.) 582-588. Verlag Chemie, Weinheim, Deerfield Beach. Florida, Basel. 1984.

22) Ohyama, Y., S. Masaki and T. Morich, Effects of inoculation of Lactobacillus plantarum and addition on glucose at ensiling on the silage quality. Jpn. J. Zootech. Sci., 44 : 404-410. 1973.

23) Phillip, L.E., L. Underhill and H. Garino, Effects of treating lucerne with an inoculum of lactic acid bacteria or formic acid upon chemical changes during fermentation, and upon the nutritive value of the silage for lambs. Grass and Forage Sci., $45: 337-344.1990$.

24) SchaAdT, H. and R.R. Johnson, Effects of maturity, fermentation time, and limestone and urea treatment on $\mathrm{D}(-)$ and $\mathrm{L}(+)$ lactic acid in corn silage. J. Dairy Sci., 51 : 802-805.1968.

25) SLYTER, L.L., Influence of acidosis on rumen function. J. Anim. Sci., $43:$ 910-929. 1976.

26) Yamamoto, K., S. Utagawa, T. Kodama and T. MORICHI, Isolation method of microorganisms (Morichi, T., ed.). 435-444. R and D Planing. Tokyo. 1986. 


\title{
サイレージにおける乳酸異性体の産生比率ならびに 乳酸菌添加が $\mathrm{L}(+)$ 乳酸産生比率に及ぼす影響
}

\author{
蔡 义民*・熊井 清雄
}

愛媛大学農学部, 松山市 790

\begin{abstract}
爱媛県下の酪農家からイタリアンライグラスとトゥモロコシサイレージ40点を集めて，サイレージ 中の乳酸異性体の産生比率を測定した。 また, 乳酸菌添加がサイレージ中の $\mathrm{L}(+)$ と D $(-)$ 乳酸異性 体の库生比率に及依高影響を明らかにするために，イタリアンライグラスとトウモロコシを材料草之 し，2回の実験を行なった，実験 1 で乳酸菌剤のS1 とCyの各添加区, 実験 2 で乳酸球菌の Enterococcus faecium 上Lactococcus lactis および䝶酸㮛菌の Lactobacillus casei の各単独添加区之 球・桿菌混合添加区（混合区）をそれぞれ設け，サイレージを調製した．酪農家サイレージの全乳酸に 占める $\mathrm{L}(+)$ 乳酸の産生比率は $32 \sim 38 \%$ 之低加った. 実験 2 は実験 1 とほぼ同様な傾向を示し, 乳酸 菌添加によってサイレージの $\mathrm{pH}$ が低下し，乳酸含量が高まった。またフリーク評点が向上し，サイ レーシの品質が明らかに改善された。サイレージ中の $L(+)$ 乳酸産生比率は無添加区に比べ, 実験 1 で 乳酸菌剤添加区が $5 \sim 10 \%(\mathrm{P}<0.05)$, 実験 2 で乳酸球菌添加区が 7 11\% $(\mathrm{P}<0.05)$, 乳酸桿菌区之混 合区が 12 14\%（P<0.05）の範沺で有意に増加した，一方，乳酸桿菌区之混合区の添加効果について は，両者間にほとんど差がなかったので，サイレージ発酵品質の改善効果は主として L. casei の添加に よることが示唆された，以上の結果，酪農家サイレージは D(-) 乳酸を高い比率で含有することととす に乳酸菌，とくに $\mathrm{L}(+)$ 乳酸のみを産生する乳酸桿菌の添加はサイレージの品質と $\mathrm{L}(+)$ 乳酸の産生 比率を高めることが明らかになった。
\end{abstract}

日畜会報, 65 (9) : 788-795，1994

*現所属：農林水産省草地試験場, 栃木県西那須野町 329-27 